\title{
Run Plan for Simulated B\&C Pond Sludge Vitrification Demonstration
}

by

c. A. Cicero

Westinghouse Savannah River Company

Savannah River Site

Aiken, South Carolina 29808

DOE Contract No. DE-AC09-89SR18035

This paper was prepared in connection with work done under the above contract number with the U.S.

Department of Energy. By acceptance of this paper, the publisher and/or recipient acknowledges the U.S. Government's right to retain a nonexclusive, royalty-free license in and to any copyright covering this paper, along with the right to reproduce and to authorize others to reproduce all or part of the copyrighted paper. 


\section{DISCLAMMER}

Portions of this document may be illegible in electronic image products. Images are produced from the best available original document. 


\section{DISCLAIMER}

This report was prepared as an account of work sponsored by an agency of the United States Government. Neither the United States Government nor any agency thereof, nor any of their employees, makes any warranty, express or implied, or assumes any legal liability or responsibility for the accuracy, completeness, or usefulness of any information, apparatus, product, or process disclosed, or represents that its use would not infringe privately owned rights. Reference herein to any specific commercial product, process, or service by trade name, trademark, manufacturer, or otherwise does not necessarily constitute or imply its endorsement, recommendation, or favoring by the United States Government or any agency thereof. The views and opinions of authors expressed herein do not necessarily state or reflect those of the United States Government or any agency thereof.

This report has been reproduced directly from the best available copy.

Available to DOE and DOE contractors from the Office of Scientific and Technical Information, P.O. Box 62, Oak Ridge, TN 37831; prices available from (615) 576-8401.

Available to the public from the National Technical Information Service, U.S. Department of Commerce; 5285 Port Royal Road, Springfield, VA 22161. 


\section{QP. Westinghouse Savannah River Company Savannah River Technology Center}

WSRC-RP-95-0991
Revision 0

Keywords: Glass, ORR, Vitrification, sludge, Low level mixed waste

November 10,1995

\section{Bun Plan for Simulated B\&C Pond Sludge Vitrification Demonstration (U)}

A formal technical task plan detailing the task objectives, quality assurance, required documentation, and personnel responsibilities will not be written for the simulated B \& C Pond sludge vitrification demonstration. Instead, this document (run plan) will serve as the formal guidance for performing and meeting the objectives of this demonstration. This document states the major objectives of this demonstration, and the necessary procedures which should be followed to ensure that the objectives will be met.

\section{Waste Description}

The surrogate waste which will be vitrified is the Oak Ridge Reservation (ORR) $B$ \& $C$ Pond sludge. This waste has been characterized by W.D. Bostick and T. Gilliam of Oak Ridge National Laboratory (ORNL) and C.M. Jantzen of the Savannah River Technology Center (SRTC). The best estimate available on the actual waste composition is given in Table 1 .

This composition should be used by Clemson University - Department of Environmental Systems Engineering (ESE) to fabricate the necessary amount of surrogate waste. Sufficient waste should be fabricated so that three melter turnovers can be produced. 
Table 1 - B \& C Pond Sludge Composition

$\begin{array}{lc}\text { Oxide } & \frac{\mathrm{Ht}}{8} \\ \mathrm{Al}_{2} \mathrm{O}_{3} & 5.4 \\ \mathrm{CaO} & 24.0 \\ \mathrm{Cr}_{2} \mathrm{O}_{3} & 0.05 \\ \mathrm{CuO} & 0.05 \\ \mathrm{Fe}_{2} \mathrm{O}_{3} & 8.3 \\ \mathrm{~K}_{2} \mathrm{O} & 2.1 \\ \mathrm{Li}_{2} \mathrm{O} & 0.0 \\ \mathrm{Na}_{2} \mathrm{O} & 0.25 \\ \mathrm{NiO}_{\mathrm{SiO}} & 0.28 \\ \mathrm{TiO}_{2} & 56.2 \\ \mathrm{ZnO} & 0.67 \\ & 0.00\end{array}$

\section{Glass Additives Description}

Preliminary glass formulations were determined by C.M. Jantzen from crucible-scale studies. The optimum glass composition determined will be used for the demonstration.

The additives necessary were determined to be silica, lithia, and soda. The targeted glass composition is given in Table 2.

$\begin{array}{cc}\text { Table } 2 \text { - } \mathrm{B} \& \mathrm{C} \text { Pond Sludge Glass Com } \\ \text { Oxide } & \frac{\mathrm{Ht}}{8} \\ \mathrm{Al}_{2} \mathrm{O}_{3} & 2.7 \\ \mathrm{CaO} & 12.0 \\ \mathrm{Cr}_{2} \mathrm{O}_{3} & 0.03 \\ \mathrm{CuO} & 0.0024 \\ \mathrm{Fe}_{2} \mathrm{O}_{3} & 4.2 \\ \mathrm{~K}_{2} \mathrm{O} & 1.03 \\ \mathrm{Li}_{2} \mathrm{O} & 7.6 \\ \mathrm{Na}_{2} \mathrm{O} & 7.6 \\ \mathrm{NiO}^{\mathrm{SiO}} & 0.14 \\ \mathrm{TiO}_{2} & 63.1 \\ \mathrm{ZnO} & 0.33 \\ \end{array}$

\section{Objectives}

The major objective of this demonstration is to demonstrate the feasibility of vitrification of surrogate B\&C Pond sludge for applicability to the Transportable Vitrification system (TVS) . Approximately three melter volumes of this sludge should be processed with the necessary glass additives to ensure that steady-state conditions have been obtained.

Due to the limited funding available for this demonstration, all necessary chemical analyses and durability testing of samples will be 
performed by SRTC. The samples which will be required from the demonstration will be listed in Attachment I. Other analyses should be performed by ESE as listed in the attachment.

In addition to the samples required from the analyses, the following data should be recorded:

- feed rates,

- volume of sludge processed,

- glass pour rates,

- volume of glass produced,

- internal temperature of the melter near the bottom refractory, during normal operation at steady-state and shortly after hothold conditions,

- power requirements needed,

- offgas operating conditions (pressures, any pluggages, etc.),

- glass temperature, if possible, and

- any processing problems identified.

The internal temperature should be measured by inserting an Inconel (or other high temperature material) thermowell with a high temperature thermocouple into the glass pool as close to the bottom of the melter as possible. This temperature measurement is needed to determine the reason for previously seen devitrification layers in the melter.

\section{Melter Selection}

Since the objective of the runs is to test the glass formulation for the future TVS demonstration, the EnVitCo EV-16 melter should be used for the demonstration. This will provide guidance to TVS personnel on the operating conditions of the melter while processing surrogate and actual $B \& C$ Pond sludge.

\section{Quality Assurance}

Quality Assurance (QA) measures identified in the Environmental Systems Engineering of Clemson University Quality Assurance Manual should be followed for the duration of the demonstration.

\section{Deliverables}

The main deliverables from this demonstration will be the samples required in the attached sample plan. Other items required are contained in the objectives section. 


\section{RUN PIAN}

\section{Run \#BC1 - simulated B \& C Pond sludge vitrification in the EV-16 Melter}

\section{Simulated sludge preparation:}

1. Prepare the simulated sludge in accordance with the composition shown in Table 1. If the sludge will be prepared at the same time as the feed is, proceed to the feed preparation section.

2. If the sludge is prepared separately, perform the analyses or take the necessary samples listed in the "Run \#BC1 - Sampling Schedule" (Attachment I) for SLDG material. Be sure that enough sample is taken for all of the analyses required by the SLUDGE analytic code (approximately 25g).

\section{Feed preparation:}

1. The feed should be mixed and on-hand before melter operation begins. This feed consists of 50 wt\% glass additives $\left(70 \% \mathrm{SiO}_{2}\right.$, $15 \% \mathrm{Li}_{2} \mathrm{O}$, and $15 \% \mathrm{Na}_{2} \mathrm{O}$ ) and 50 wt: simulated sludge. Prepare the feed according to the ESE derived spreadsheets.

2. Perform the analyses or take the necessary samples Iisted in the "Run \#BCl - Sampling Schedule" (Attachment I) for FEED material. Be sure that enough sample is taken for all of the analyses required by the SLUDGE analytic code (approximately 25g).

3. Record the mass of feed that is to be melted.

\section{Melting of the feed;}

1. Heat-up the melter according to the "EnvitCo Furnace startup Procedure" and follow the guidelines given to vitrify the feed.

2. The initial feed rate should be recorded in the log book and rerecorded every time the feed rate changes along with the time of change. The VOLUME of the FEED material should be monitored throughout the run so that the melt rate can be kept constant.

3. Once the melter reaches steady state operating conditions, the following should be determined:

a. glass production rate per hour (based on mass of glass produced per unit time),

b. redox information required by the $\mathrm{FE} 2 \mathrm{FE} 3$ analytic code, and the following samples should be taken:

a. samples that are to be submitted under the GLASSC, GLASSP, GLASST and GLASSX analytic codes.

b. archive samples.

4. The total amount of glass produced and the time it took to produce the glass should be recorded. 
5. An estimate of the amount of offgas produced should be made and the samples listed under the OFFG, OGDP, and COND should be taken as necessary and possible. These samples can be taken anytime during the run, as long as they are taken before proceeding to the next step.

6. Once all of the feed has been vitrified, the melter should be shut-down according to the "EnVitCo Furnace Shutdown Procedure". The melter refractories and electrodes should be examined for any wear or corrosion. If corrosion or wear is present, a sample should be submitted to WSRC under the TNKSOL analytic code. 
ATTACHMENT I - SAMPLE PLAN FOR \#BC1 RUN

\begin{tabular}{|c|c|c|c|c|}
\hline Material & Description & Analytic Code & \#Samples & Responsibility* \\
\hline \multirow[t]{7}{*}{ SLDG } & Simulated $B \& C$ Pond & SLUDGE & 3 & SRTC \\
\hline & sludge (only if & SPGRAV & 3 & ESE \\
\hline & fabricated & WTLOSS & 3 & ESE \\
\hline & separately) & WT:SOL & 3 & ESE \\
\hline & & GLASST & 2 & SRTC \\
\hline & & PHSLDG & 3 & ESE \\
\hline & & ARCHIV & 3 & ESE \\
\hline & & & & \\
\hline \multirow[t]{6}{*}{ FEED } & Melter feed & SLUDGE & 3 & SRTC \\
\hline & & WTLOSS & 3 & ESE \\
\hline & & WT: SOL & 3 & ESE \\
\hline & & SPGRAV & 3 & ESE \\
\hline & & VOLUME & $5 \star \star$ & ESE \\
\hline & & ARCHIV & 3 & ESE \\
\hline & & & & \\
\hline \multirow[t]{6}{*}{ GLAS } & Glass produced & GLASSC & 3 & SRTC \\
\hline & & GLASSP & 2 & SRTC \\
\hline & & GLASST & 2 & SRTC \\
\hline & & ARCHIV & 5 & ESE \\
\hline & & FE2FE3 & 3 & SRTC \\
\hline & & GLASSX & 3 & SRTC \\
\hline & & & & \\
\hline \multirow[t]{2}{*}{ OFFG } & Direct offgas & METH5P & 2 & ESE \\
\hline & sample & OGMMST & 2 & ESE \\
\hline \multirow{3}{*}{ OGDP } & & & & \\
\hline & Offgas deposit & OFEXRD & 2 & SRTC \\
\hline & & & & \\
\hline \multirow[t]{2}{*}{ COND } & Scrub solution/ & OGMMST & as possible & ESE \\
\hline & condensate & & & \\
\hline & & & & \\
\hline \multirow[t]{4}{*}{ SPEC } & Any special & TNKSOL & as needed & SRTC \\
\hline & samples needed & & & \\
\hline & which are not & & & \\
\hline & covered above & & & \\
\hline \multicolumn{5}{|c|}{ *The responsibility refers to the group responsible for performing the } \\
\hline \multirow{3}{*}{\multicolumn{5}{|c|}{$\begin{array}{l}\text { analyses. ESE will be responsible for taking all samples. } \\
\text { **An initial volume measurement is to be taken, as well as four other volume } \\
\text { measurements during melting. The time that these samples are taken should }\end{array}$}} \\
\hline & & & & \\
\hline & & & & \\
\hline be recorded & so that the melt $r$ & with time can & e determine & \\
\hline
\end{tabular}


N.E. Bibler, 773-A

D.E. Bickford, 773-A

P.R. Burket, 773-23A

G.S. Bumgarner, 773-41A

D.A. Crowley, 773-23A

E.F. Duhn, 773-A

E.K. Hansen, 773-23A

J.R. Harbour, 773-43A

D.B. Helton, 773-41A

E.W. Holtzscheiter, 773-A

C.M. Jantzen, 773-A

L.E. Landon, 704-T

K.E. Mottel, 773-43A

M.J. Plodinec, 773-A

C.T. Randall, 704-T

M.E. Smith, 773-23A

J.C. Whitehouse, 773-23A

S.R. Young, 773-23A

J.R. Zamecnik, 773-23A

GT Files

TIM 703-43A 